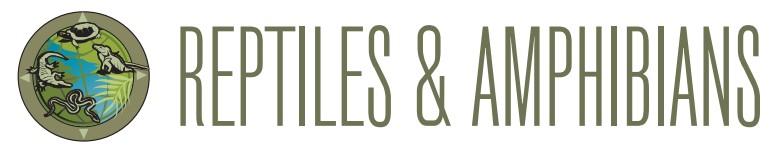

\title{
Land Snails Feeding on Dead Frogs
}

Omkar Yadav ${ }^{1}$, Mayur Jadhav ${ }^{2}$, Saurabh Kininge ${ }^{3}$, Parashuram Bajantri ${ }^{4}$, and Amrut Bhosale

1'Amdar Shashikant Shinde Mahavidyalaya, Medha, Satara, Maharashtra (sarpaveda@gmail.com)

${ }^{2}$ Department of Botany, Shivaji University, Kolhapur, Maharashtra (jadhavm790@gmail.com [corresponding author]) ${ }^{3}$ Department of Agrochemical and Pest Management, Shivaji University, Kolhapur, Maharashtra (saurabhkininge01@gmail.com) ${ }^{4}$ Karnataka Forest Department, Anshi Wildlife Range, Kali Tiger Reserve, Uttar Kannada, Karnataka (jaishreeram49@gmail.com) 5Sadguru Gadage Maharaj College, Karad, Satara, Maharashtra (amrutb18@gmail.com)

A nurans are regular food for many predators and scavengers, including a variety of invertebrates (e.g., Hinshaw and Sullivan 1990; Toledo 2005; Dehling 2007; Yadav et al. 2021). Land snails feed on various organic materials that include green or dead herbaceous plants, leaf litter, discarded fruit remnants, and other invertebrates (e.g., Hotopp et al. 2013; Imevore and Ajayi 1993; Bhosale et al. 2021a); however, they also consume empty snail shells, sap, animal scat and carcasses, and even limestone rock or cement. Carnivorous snail species feed on nematodes and other snails (e.g., Ismail et al. 2003; Ramzy 2009; Bhosale et al. 2021b). Herein we report two observations of land snails feeding on the skin of dead frogs.

At 1042 h on 28 August 2017, on a tarred road at Balemane, Karwar, Uttar Kannada, Karnataka, India $\left(14.89972^{\circ} \mathrm{N}, 74.43527^{\circ} \mathrm{E}\right.$; elev. $40 \mathrm{~m}$ asl), we observed an ariophantid snail (Ariophanta cf. belangeri) feeding on a roadkilled Indian Skipper Frog (Euphlyctis cyanophlyctis) (Fig. 1). Upon closer examination, the snail clearly had been feeding on the skin rather than the flesh of the frog. At 0729 h on 12

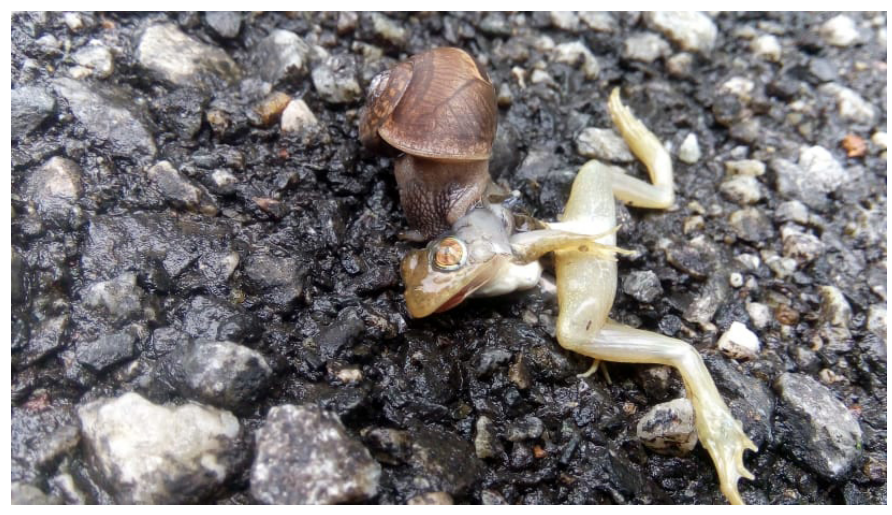

Fig. 1. An ariophantid snail (Ariophanta cf. belangeri) feeding on the skin of a road-killed Indian Skipper Frog (Euphlyctis cyanophlyctis). Photograph by Parashuram Bajantri.
August 2018, on a roadside at Kolhapur, Maharashtra, India $\left(16.67420^{\circ} \mathrm{N}, 74.2420^{\circ} \mathrm{E}\right.$; elev. $571 \mathrm{~m}$ asl), we observed a Horntail Snail (Macrochlamys indica) feeding on the outer epidermis of a road-killed Syhadra Cricket Frog (Minervarya syhadrensis) (Fig. 2).

That both snails were feeding on skin and apparently avoiding muscular parts is of interest and worthy of further research, especially since amphibian integumentary gland secretions contain toxins that can deter at least some predators and presumably some scavengers (Clarke 1997). These observations also suggest that land snails more frequently scavenge dead vertebrates than has been recorded.

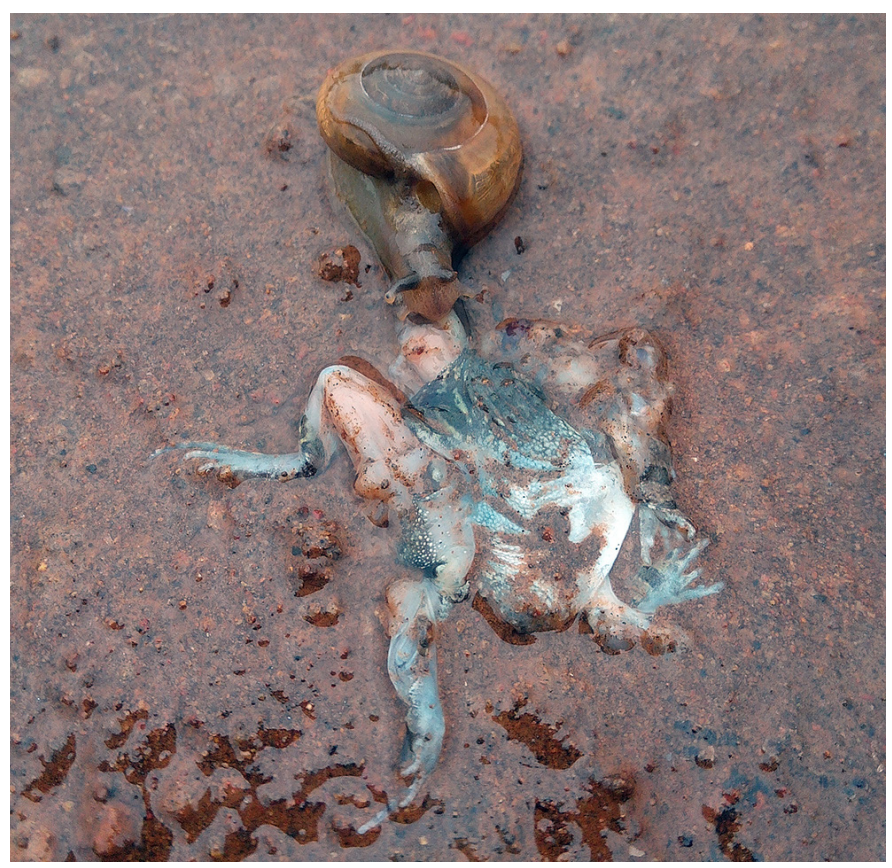

Fig. 2. A Horntail Snail (Macrochlamys indica) feeding on the outer epidermis of a road-killed Syhadra Cricket Frog (Minervarya syhadrensis). Photograph by Saurabh Kininge. 


\section{Acknowledgement}

We are grateful to Varad Giri for his support in writing this note.

\section{Literature Cited}

Bhosale A.R., A.J. Saadi, C.M. Wade, T.U. Thackeray, A.S. Tamboli, S.K. Kadam, D.V. Muley, and D.C. Raheem. 2021a. Varadia, a new helicarionoidean semi-slug genus from India's Western Ghats (Stylommatophora: Helicarionoidea). European Journal of Taxonomy 757: 50-79. https://doi. org/10.5852/ejt.2021.757.1413.

Bhosale, A., T. Thackeray, and B. Rowson. 2021b. Perrottetia rajeshgopali, a new species of Perrottetia Kobelt, 1905 (Stylommatophora: Streptaxidae) from the Western Ghats, India. Archiv für Molluskenkunde 150: 45-54. https://doi. org/10.1127/arch.moll/150/045-054.

Clarke, B.T. 1997. The natural history of amphibian skin secretions, their normal functioning and potential medical applications. Biological Reviews 72: 365-379. https://doi.org/10.1111/j.1469-185X.1997.tb00018.x.

Dehling, D.M. 2007. Smilisca sordida (Drab Tree Frog). Predation. Herpetological Review 38: 444.

Hinshaw, S.H. and B.K. Sullivan. 1990. Predation on Hyla versicolor and Pseudacris crucifer during reproduction. Journal of Herpetology 24: 196-197. https://doi. org/10.2307/1564228.

Hotopp, K.P., T.A. Pearce, J.C. Nekola, J. Slapcinsky, D.C. Dourson, M. Winslow, G. Kimber, and B. Watson. 2013. Land Snails and Slugs of the Mid-Atlantic and Northeastern United States. Carnegie Museum of Natural History, Pittsburgh, Pennsylvania, USA. <http://www.carnegiemnh.org/science/mollusks/index.html>.

Imevbore, E.A. and S.S.Ajayi. 1993. Food preference of the African giant snail, Archachatina marginata in captivity. African Journal of Ecology 31: 265-267.

Ismail, S.A.A., S.A.A. El-Massry, M.M. Khattab, and A.S. Hassan. 2003. Daily activity and damage caused by Eobania vermiculata Müller (Gastropoda) in citrus orchards. Egyptian Journal of Agricultural Research 18: 1-6.

Ramzy, R.R. 2009. Biological and Ecological Studies on Land Snails at Assiut, Egypt. Unpublished M.Sc. Thesis, Faculty of Science, Assiut University, Asyut, Egypt.

Toledo, L.F. 2005. Predation of juvenile and adult anurans by invertebrates: Current knowledge and perspectives. Herpetological Review 36: 395-399.

Yadav, O., N. Junghare, M. Sapkal, and P. Kadam. 2021. A carabid beetle larva (Epomis sp.) preying on a Leith's Leaping Frog (Indirana leithii). Reptiles \& Amphibians 28: 161-162. https://doi.org/10.17161/randa.v28i1.15381. 